\title{
HUBUNGAN ANTARA KADAR NITROGEN OKSIDA DENGAN JUMLAH PENDERITA ISPA DI SEKITAR LAPINDO
}

\author{
Erny Tri Handayani, Suroso Bambang Eko Warno, Musta'in
}

\begin{abstract}
The emerging mud volcano known as Lumpur Lapindo Sidoarjo represents a significant disaster induced by industrial activities. One of the immediate impacts caused by Lumpur Lapindo in Porong area is air polution such $\mathrm{NO}_{\mathrm{x}}$. Such polution may affect human health namely the upper respiratory disturbances known as ISPA. This study was directed at surveying existing temperature and humidity, wind velocity and direction, discharge of $\mathrm{NO}_{x}$ gas, ambient air and to enumerate people suffering from ISPA in Puskesmas Jabon and Porong, to establish an association between $\mathrm{NO}_{x}$ concentration around Lumpur Lapindo site with the increasing number of people suffering from ISPA.

This study was driven as a cross-sectional descriptive exercise. Data were collected on air temperature and humidity, wind velocity and direction, discharge of $\mathrm{NO}_{x}$ to be entered into descriptive analyses.

The survey resulted in air temperature of $31.1^{\circ} \mathrm{C}$, humidity $62.4 \%$, wind velocity of $2.89 \mathrm{~m} / \mathrm{s}$ and a wind derection from the north to south. The chemical parameter in the survey was $\mathrm{NO}_{\times}$gas in ambient air of 24.7 $\mu g / \mathrm{Nm}^{3}$ which was still below the designated ambent air quality standard in the Per.Gub Jatim No. 10 Tahun 2009. Records indicated that the number of people suffering from ISPA have been increasing since 2006 2012. This did not have any relationship with the $\mathrm{NO}_{\mathrm{x}}$ situation, instead it may be caused by other factors.

The suggestion offered to BPLS was for it to keep going green and for its workers to wear masks. The Puskesmas was encouraged to do something about the ISPA patients. The community were encouraged to plant shrubberies and trees to create green environment and to keep in touch with the Puskesmas.
\end{abstract}

Keywords $\quad:$ Gas $\mathrm{NO}_{\mathrm{x}}$, upper respiratory disorder, Saltzman

\section{PENDAHULUAN}

Latar Belakang

Udara adalah kumpulan gas yang terbentuk pada lapisan yang mengelilingi bumi (Fardiaz.2004). Pencemaran udara adalah masuknya atau dimasukkannya zat, energi dan / atau komponen lain ke dalam udara ambien oleh kegiatan manusia, sehingga mutu udara ambien turun sampai ketingkat tertentu yang menyebabkan udara ambien tidak dapat memenuhi fungsinya (PP RI No.41 Tahun 1999).

Dari beberapa macam komponen pencemar udara, yang paling banyak berpengaruh dalam pencemaran udara adalah karbon monoksida (CO), nitrogen oksida $\left(\mathrm{NO}_{x}\right)$, belerang oksida $\left(\mathrm{SO}_{x}\right)$, hidro karbon dan partikel (Arya Wardhana, 2001).

Sumber pencemaran udara dapat berupa kegiatan yang bersifat alami dan dari aktivitas manusia. Contoh sumber alami adalah akibat letusan gunung berapi, kebakaran hutan, debu. Sumber pencemaran udara dari aktivitas manusia adalah transportasi, industri, sampah pada proses pembakaran dan rumah tangga. Salah satu contoh akibat dari aktivitas industri yang banyak berdampak pada lingkungan dan mengganggu kesehatan manusia adalah bencana Lumpur Lapindo (Soedomo, 2003).

Akibat adanya semburan lumpur Lapindo di daerah Porong adalah terjadinya pencemaran udara berupa gas $\mathrm{H}_{2} \mathrm{~S}, \mathrm{NO}_{x}, \mathrm{SO}_{x}$ dan Hidrokarbon. Polusi udara yang berasal dari semburan lumpur Lapindo tersebut dapat mengganggu kesehatan masyarakat pada wilayah yang terkena dampak yaitu Tanggulangin, Porong dan Jabon. Gangguan kesehatan yang banyak di alami oleh masyarakat yang terkena dampak Lumpur Lapindo adalah gangguan saluran pernafasan. Berdasarkan data yang diperoleh dari Puskesmas Tanggulangin jumlah penderita ISPA pada tahun 2005 (sebelum terjadi semburan lumpur Lapido) adalah 11.800 orang, tahun (2006) 12.164 orang, tahun (2007) 12.628 orang, tahun (2008) 13.261 orang, tahun (2009) 15.702 orang, tahun (2010) 16.841 orang dan pada tahun (2011) 16.976 orang. Jumlah penderita ISPA di Puskesmas Porong pada tahun 2005 (sebelum terjadi lumpur Lapindo) adalah 24.719 orang, tahun (2006) 28.640 orang, tahun (2007) 42.626 orang, tahun (2008) 42.652 orang, tahun (2009) 52.543 orang, tahun (2010) 61.882 orang dan pada tahun (2011) 63.750 orang.

Guru besar sekaligus Dekan Fakultas Kesehatan Masyarakat Airlangga yang juga anggota tim TKKP, Mukono, mengatakan gas-gas yang muncul di permukiman sekitar lokasi Lapindo itu sangat berbahaya, bersifat karsinogenik, dan dapat memicu kanker. Menurut hasil Penelitian Tim Kajian Kelayakan Permukiman (TKKP) akibat semburan lumpur 
ditemukan adanya nitrogen dioksida $\left(\mathrm{NO}_{2}\right)$ yang mudah terbakar muncul di rumah-rumah warga. TKKP menemukan $\mathrm{NO}_{2}$ sebesar $0,116 \mathrm{ppm}$ di RT 03, Siring Barat. Angka ini sangat mengkhawatirkan karena ambang baku mutu yang diizinkan-sesuai dengan Keputusan Kepala Daerah Tingkat I Jatim Nomor 129 Tahun 1996untuk $\mathrm{NO}_{2}$ hanya 0,05 ppm. (http://selokartojaya.blogspot.com/2010/09 /betahan-hidupmil-zonamaut-lapindo html). Adanya $\mathrm{NO}_{2}$ di udara dengan konsentrasi lebih dari 0,05 ppm akan menyebabkan gangguan pernafasan akut pada manusia (Soedomo, 2001).

\section{Tujuan Penelitian}

Mengetahui kadar gas $\mathrm{NO}_{\mathrm{x}}$ sekitar Lapindo dan hubungannya dengan peningkatan jumlah penderita ISPA Tahun 2012.

\section{METODE PENELITIAN}

Jenis Penelitian, Populasi, Besar Sampel, Titik Sampling dan Jenis Sampel

Jenis penelitian ini adalah penelitian deskriptif yaitu menggambarkan tentang hubungan antara gas $\mathrm{NO}_{\mathrm{x}}$ dengan peningkatan jumlah penderita ISPA, penelitian ini merupakan penelitian cross sectional. Populasi dalam penelitian adalah udara yang ada di sekitar semburan lumpur Lapindo yang terletak di Dusun Balongnongo Desa Renokenongo, Kecamatan Porong, Kabupaten Sidoarjo dan wilayah pemukiman yang ada di sekitar semburan lumpur Lapindo, pengambilan sampel dilakukan di 3 titik sampling dan pada masing - masing titik dilakukan 3 kali pengukuran.

Berdasarkan jenisnya, sampel yang diambil termasuk sampel gabungan waktu dan gabungan tempat. dimana pengukuran dilakukan 3 kali dengan interval waktu (pagi pukul 06.00 - 09.00 WIB, siang pukul $11.00-14.00$ WIB, sore pukul 15.00 - 18.00 WIB) dan pengukuran dilakukan di 3 titik yang berbeda yaitu 1 titik pada daerah arah angin dominan di sumber lumpur dan 2 titik pada daerah arah angin dominan di wilayah permukiman yang ada di sekitar lokasi semburan lumpur Lapindo.

\section{Analisis Data}

Data yang diperoleh akan diolah dalam bentuk table dan selanjutnya dianalisis secara deskriptif.

\section{HASIL PENELITIAN DAN PEMBAHASAN}

TABEL 1

HASIL REKAPITULASI PENGUKURAN PARAMETER FISIK DAN KIMIA SEKITAR LAPINDO TAHUN 2012

\begin{tabular}{|c|l|c|c|}
\hline No. & \multicolumn{1}{|c|}{ Parameter } & Hasil & Baku Mutu \\
\hline 1. & Suhu dan kelembaban udara & $31,1^{\circ} \mathrm{C}$ dan $62,4 \%$ & - \\
\hline 2. & Kecepatan angin & $2,86 \mathrm{~m} / \mathrm{s}$ & - \\
\hline 3. & Arah angin & Utara menuju ke Selatan & - \\
\hline 4. & Kadar gas Nitrogen Oksida $\left(\mathrm{NO}_{\mathrm{x}}\right)$ & $0,013 \mathrm{ppm}$ atau $24,7 \mu \mathrm{gg} / \mathrm{Nm}^{3}$ & $\begin{array}{c}0,05 \mathrm{ppm} \text { atau } 92,5 \\
\mu \mathrm{g} / \mathrm{Nm}^{3}\end{array}$ \\
\hline
\end{tabular}

\section{Suhu dan Kelembaban}

Hasil rata - rata keseluruhan untuk pengukuran suhu dan kelembaban udara di Tanggul Selatan, Desa Pejarakan dan Desa Mindi adalah sebesar $31,1^{\circ} \mathrm{C}$ dengan kelembaban 62,4 $\%$. Hal tersebut menunjukkan bahwa dalam udara masih terkandung uap air. Suhu yang menurun

$$
\begin{array}{lll}
\mathrm{N}_{2} & + & \mathrm{O}_{2} \longrightarrow \\
2 \mathrm{NO} & + & \mathrm{O}_{2} \longrightarrow 2 \mathrm{NO}^{2} \\
2 \mathrm{NO}_{2}
\end{array}
$$

Kondisi udara yang lembab akan membantu proses pengendapan bahan pencemar seperti $\mathrm{NO}_{2}$, sebab dengan keadaan udara yang lembab maka beberapa bahan pencemar seperti $\mathrm{NO}_{2}$ akan berikatan dengan air yang ada dalam udara dan membentuk hujan asam sehingga dapat pada permukaan bumi, dapat menyebabkan peningkatan kelembaban udara relatif, sehingga akan meningkatkan efek korosif bahan pencemar di daerah yang udaranya tercemar. Sedangkan dengan suhu yang meningkat, akan meningkat pula kecepatan reaksi suatu bahan kimia seperti berikut (Mukono, 2003) :

meningkatkan efek korosif di daerah tersebut (http://putraprabu.wordpress.com/2009 /01/02/aspek-klimatologi-pencemaran-udara/) Salah satu reaksi yang diduga terjadinya hujan asam di atmosfer yaitu sebagai berikut (Fardiaz, 2004) : 


$\begin{array}{lllll}2 \mathrm{NO}_{2} & + & \mathrm{H}_{2} \mathrm{O} & \longrightarrow & \longrightarrow \\ 3 \mathrm{NO}_{2} & + & \mathrm{H}_{2} \mathrm{O} & \longrightarrow & \mathrm{HNO}_{3}+ \\ 2 \mathrm{HNO}_{3}+\mathrm{NO} & \mathrm{HNO}_{2}\end{array}$ atau

Dengan adanya kandungan air di udara ambien maupun di dalam tubuh, maka dapat mengubah $\mathrm{NO}_{x}$ menjadi nitrat dan nitrit yang bersifat toksik pada tubuh dan dapat mengakibatkan gangguan pada saluran pernapasan. Saat manusia terpapar Nitrogen dioksida lebih dari 0,05 ppm, maka akan dapat menyebabkan gangguan pernafasan yang bersifat akut (ISPA) (Soedomo, 2001).

Sedangkan berdasarkan hasil pengukuran kadar gas $\mathrm{NO}_{x}$ sekitar Lapindo, yang dilakukanpada Tanggul Selatan, Desa Pejarakan dan Desa Mindi diperoleh hasil sebesar 0,013 ppm atau $24,7 \mu \mathrm{g} / \mathrm{Nm}^{3}$. Hasil tersebut menunjukkan bahwa kadar gas $\mathrm{NO}_{x}$ sekitar Lapindo tidak ada hubungannya dengan peningkatan jumlah penderita ISPA yang dialami oleh masyarakat Porong dan Jabon yang merupakan daerah yang terkena dampak Lumpur Lapindo. Akan tetapi apabila tubuh manusia terpapar gas $\mathrm{NO}_{2}$ setiap hari, walaupun kadarnya masih di bawah 0,05 ppm, maka lama kelamaan akan menumpuk di dalam tubuh dan menyebabkan terjadinya PPOM. Dengan masuknya $\mathrm{NO}_{2}$ ke dalam tubuh melalui saluran pernapasan maka akan menyebabkan terjadinya pemajanan pada dinding sel, yang mengakibatkan kerusakan pada membran sel, DNA dan protein dengan mekanisme sebagai berikut : gas $\mathrm{NO}_{2}$ dapat masuk ke saluran pernapasan dan menyebabkan terjadinya peradangan bronkus. Peradangan bronkus akan menyebabkan terjadinya pengeluaran mediator peradangan seperti histamin, prostaglandin dan slow reacting substance $A$. Mediator tersebut akan merangsang makrofag mengeluarkan oksidan seperti $\mathrm{H}_{2} \mathrm{O}_{2}, \mathrm{HOCl}$, dan $\mathrm{OH}$ - yang dapat merusak membran sel, DNA ataupun protein. Adanyan oksidan yang mengenai membran sel akan mengakibatkan kerusakan pada sel, apabila oksidan bercampur dengan DNA maka akan terjadi mutasi gen, dan apabila oksidan mengenai protein maka akan merusak enzim, sehingga struktur sel akan rusak dan terjadi predisposisi PPOM (Mukono, 2003).

\section{Kecepatan dan Arah Angin}

Hasil pengukuran kecepatan angin di Tanggul Selatan, Desa Pejarakan dan Desa Mindi adalah sebesar $2,86 \mathrm{~m} / \mathrm{s}$ dengan arah angin dari Utara menuju ke Selatan. Kecepatan angin yang kuat akan membawa polutan terbang kemanamana dan dapat mencemari udara di daerah lain. Sebaliknya, apabila kecepatan angin lemah polutan akan menumpuk ditempat dan dapat mencemari udara di lingkungan permukiman yang terdapat disekitar lokasi pencemaran tersebut (http://abhoe-niyh.blogspot.com/2009/05

/pencemaran- udara- pada sampah.html).

\section{Gas Nitrogen Oksida Dan Peningkatan Jumlah Penderita ISPA}

Berdasarkan pada hasil yang ditunjukkan oleh tabel di atas, dapat diketahui bahwa peningkatan jumlah penderita ISPA tidak ada hubungaannya dengan kadar gas $\mathrm{NO}_{x}$ sekitar semburan Lumpur Lapindo. Karena berdasarkan hasil pengukuran yang telah dilakukan pada tanggal 11 Mei tahun 2012 di sekitar Lumpur Lapindo yaitu Tanggul Selatan, Desa Pejarakan dan Desa Mindi diperoleh hasil kadar gas $\mathrm{NO}_{x}$ masih di bawah baku mutu udara ambien. Hal tersebut menunjukkan bahwa peningkatan jumlah penderita ISPA yang dialami oleh masyarakat yang terkena dampak Lumpur Lapindo dari tahun ke tahun bukan dikarenakan kadar gas Nitrogen Oksida $\left(\mathrm{NO}_{\mathrm{x}}\right)$ udara ambien sekitar semburan Lumpur Lapindo melainkan disebabkan oleh faktor lain seperti :

a. Dari bahan kimia seperti : Hydrokarbon, debu dan $\mathrm{CO}$ yang bersumber dari aktivitas manusia dan kejadian alamiah. Beberapa aktivitas manusia yang dapat menimbulkan terjadinya pëncemaran yaitu industri, transportasi, PLTU, hasil pembakaran sampah dan asap dapur (Soedjono, 1991).

Sedangkan kejadian alami yang menjadi sumber pencemar yaitu kebakaran hutan, penyebaran benang sari dari beberapa jenis bunga (seperti jenis bunga dandelion), erosi tanah oleh angin, gunung meletus, penguapan bahan organik dari beberapa jenis daun (seperti jenis pohon cemara yang mengeluarkan hidrokarbon), dekomposisi dari beberapa jenis bakteri pengurai dan deburan ombak laut (sulfat dan garam) (Darmono,2001).

b. Dari mikrobologi seperti: Bakteri Streptococcus pneumonia (pneumococci) dan virus Hemophillus influenzae yang bersumber dari limbah biologi yang tidak diolah dengan baik, dari Rumah Sakit yang memiliki ruang rawat inap penyakit menular dan dari laboratorium Rumah Sakit (Depkes RI, 1995).

c. Usia

Anak yang usianya masih balita dan orang yang sudah lanjut usia, kemungkinan untuk 
menderita atau terkena penyakit ISPA lebih besar bila dibandingkan dengan anak yang usianya remaja, karena daya tahan tubuhnya lebih rendah (http:// xamthoneplus.com/ penyakit-ispa).

Jika dilihat dari hasil rekapitulasi di atas, dapat diketahui bahwa persentase penduduk yang usianya rentan untuk terkena penyakit ISPA yaitu sebesar $23 \%$.

Selain itu penyakit ISPA juga bisa disebabkan akibat kontak yang terjadi di tempat kerja dan juga akibat dari asap kendaraan bermotor ketika melakukan aktivitas di luar rumah. Sebagaimana telah diketahui bahwa sekitar sebesar $75 \%$ terjadinya pencemaran udara disebabkan oleh aktivitas transportasi (Wardhana, 2001)

Sebagian besar orang setiap hari pasti akan melakukan aktivitasnya di luar rumah, sehingga tidak menutup kemungkinan saat melakukan aktivitas di luar rumah tersebut polutan masuk kedalam tubuh melalui saluran pernapasan. Demikian juga halnya dengan peningkatan jumlah penderita ISPA yang dialami oleh masyarakat yang terkena dampak Lumpur Lapindo ini, bisa juga diakibatkan karena terpapar oleh polutan dari asap kendaraan bermotor saat melakukan aktivitas di luar rumah dan bisa juga terpapar di lingkungan kerja. Karena berdasarkan data sekunder yang telah diperoleh terdapat beberapa warga yang di lingkungan kerjanya sangat berpotensi untuk terpapar bahan polutan, seperti tukang batu, karyawan perusahaan, pembantu rumah tangga, pedagang keliling, TNI, POLRI, buruh tani dan petani.

\section{KESIMPULAN}

Di sekitar semburan Lumpur Lapindo didapatkan suhu sebesar $31,1{ }^{\circ} \mathrm{C}$, kelembaban udara $62,4 \%$ dan kecepatan angin sebesar 2,86 $\mathrm{m} / \mathrm{s}$, dengan arah angin dominan pada saat penelitian dari utara menuju ke selatan. Sedangkan untuk kadar gas Nitrogen oksida $\left(\mathrm{NO}_{x}\right)$ udara ambien dibawah nilai ambang batas yaitu sebesar 0,013 ppm atau $24,7 \mu \mathrm{g} / \mathrm{Nm}^{3}$.

Data yang diperoleh dari Puskesmas Jabon dan Porong terjadi peningkatan jumlah penderita ISPA dari Tahun 2006 - 2011 yaitu : di Puskesmas Jabon jumlah penderita ISPA tahun 2006 sebanyak 13.162 orang, jumlah penderita ISPA tahun 2011 sebanyak 15.481. Untuk Puskesmas Porong jumlah penderita ISPA tahun 2006 sebanyak 28.640 orang, jumlah penderita ISPA tahun 2011 sebanyak 63.750 orang.

Peningkatan jumlah penderita ISPA tidak ada hubungannya dengan kadar gas Nitrogen oksida $\left(\mathrm{NO}_{x}\right)$ udara ambien sekitar semburan
Lumpur Lapindo tapi dimungkinkan adanya faktor lain.

\section{DAFTAR RUJUKAN}

Abhoe, 2009. Pencemaran Udara Pada Sampah. http://abhoe-

niyg.blogspot.com/2009/05/pencemaranudara-padasampah.html.

Ahira, Anne, Kenali ISPA untuk Penanganan Sedini Mungkin.

http://www.anneahira.com/ispa.htm.

Anonymous, 2012. Banjir Lumpur Panas Sidoarjo. http: //id.wikipedia.org/wiki/Banjir lumpur panas Sidoarjo\#Lokasi.

Anonymous, 2006. Himpunan Peraturan Perundangan Lingkungan Hidup. Surabaya, Bapedal Propinsi Jawa Timur.

Anonymous, 2010. Study Tentang Kadar Debu Pada Pabrik Kayu UD. Hasil Swamill di Kawasan Industri Desa Lomanis Kecamatan Cilacap Tengah Kabupaten Cllacap Tahun 2010. http://dc99.4 shared.com/doc/3 WUZgtqM/ preview.html.

Anonymous. 2006. Survei Cepat Dampak Semburan Lumpur Panas Di Kecamatan Porong Kabupaten Sidoarjo Jawa Timur. http://www.ekologi.litbang.depkes.go.id/da ta/news/SURVEI\%20CEPAT\%20SIDOARJO. pdf

Darmono, 2001. Lingkungan Hidup dan Pencemaran. Jakarta, Indonesia University Press.

Fardiaz, Srikandi, 2004. Polusi Air \& Udara. Yogyakarta, Kanisius.

Kris, 2011. Penyakit ISPA. http://xamthoneplus.com/penyakit-ispa.

Manurung, Robert, 2010. Bertahan Hidup di Zona Maut Lapindo. http:/selokartojaya.blogspot.com/2010/09/ bertahan-hidup-di-zona-maut-lapindo.html

Mukono, 2003. Pencemaran Udara dan Pengaruhnya Terhadap Gangguan Saluran Pernafasan. Surabaya, Airlangga University Press.

Mukono, 2006. Prinsip Dasar Kesehatan Lingkungan. Surabaya, Airlangga University Press.

Nahattands, Lambock V. 1999. Peraturan Pemerintah Republik Indonesia Nomor 41 Tahun 1999 Tentang Pengendalian Pencemaran Udara, http://factfor.us/phocadownload/pp no 41 thn 1999 pengendalian pencemaran udara.pdf.

Prabu, 2009. Aspek Klimatologi Pencemaran Udara.

http://putraprabu.wordpress.com/2009/01/ 02/aspek-klimatologi-pencemaran-udara/ 
Soedomo, Moestikahadi, 2001. Pencemaran Udara. Bandung, ITB Bandung.

Soekarwo, 2009. Peraturan Gubernur Jawa Timur Nomor 10 Tahun 2009 Tentang Baku Mutu Udara Ambien dan Emisi Sumber Tidak Bergerak di Jawa Timur.http://www.depkes.go.id/downlouds /udara.PDF.
Walhi Jatim, 2006. Kandungan Lumpur Lapindo Ancam Ribuan Nyawa Manusia. http://walhijatim.blogspot.com/2006/07/ka ndungan-lumpur-lapindo-ancamribuan.html

Wardhana, Wisnu Arya, 2001. Dampak Pencemaran Lingkungan. Yogyakarta, Andi. 